DOI: http://dx.doi.org/10.12775/ths.2015.009

\author{
Mirosława Buchholtz \\ Department of English, \\ Nicolaus Copernicus University \\ Miroslawa.Buchholtz@umk.pl
}

\title{
Stopovers and Connecting Flights. A Discussion of Where is American Literature? by Caroline F. Levander
}

\begin{abstract}
The face of American literature is changing in the era of digital technologies. This fact has been recognized by different generations of American scholars defining the scene today. For example, both J. Hillis Miller and Caroline F. Levander admit that the traditional understanding of literature as a selection of venerated texts is over as the internet both opens up new vistas and poses new challenges to the studying and teaching of literature, and especially national literature. It is time again to pose simple questions in an attempt to redefine the current discourse in literary research. Levander's book, read at the background of past and recent scholarship, serves as a starting point for discussions concerning American literature viewed as a dynamic field of collaborative production.
\end{abstract}

Keywords: American literature; history of North America; reception studies; comparative studies; postcolonial studies; distant reading; migration; narrative; cognitive literary studies.

It is pleasant to believe that once upon a time all research began with what has since come to be known as typical journalistic questions: "who, what, why, when, and where." Only later did process-oriented minds add "how," and quantity-addicted ones: "how much," and "how many." Academic research, however, has long dispensed with such fairy-tale basics and devised sophisticated, polysemic methodological configurations, in which 
the primal question words would need to be unearthed from under a thick layer of metaknowledge. This discursive accretion must have started long ago if already at the end of the $16^{\text {th }}$ century Michel de Montaigne made remarks which hold true to this day:

There is more ado to interpret interpretations than to interpret things, and more books upon books than upon any other subject; we do nothing but comment upon one another. Every place swarms with commentaries; of authors there is great scarcity. Is it not the principal and most reputed knowledge of our later ages to understand the learned? Is it not the common and final end of all studies? Our opinions are grafted upon one another; the first serves as a stock to the second, the second to the third, and so forth; thus step by step we climb the ladder; whence it comes to pass that he who is mounted highest has often more honour than merit, for he is got up but an inch upon the shoulders of the last, but one. (1877)

This claim is couched as common knowledge about clearly visible actions and processes in which the speaker is complicit. The use of rhetorical yes-no questions and of first-person pronouns is ample evidence of both certainty and complicity. Before Montaigne makes these frequently quoted (and rarely heeded) remarks (or warnings) about the scarcity (perhaps even death?) of genuine authors, he poses the following rhetorical questions that begin with the words "who" and "when" in Book III Chapter XIII (Of Experience) of his famous Essays:

Who will not say that glosses augment doubts and ignorance, since there's no book to be found, either human or divine, which the world busies itself about, whereof the difficulties are cleared by interpretation. The hundredth commentator passes it on to the next, still more knotty and perplexed than he found it. When were we ever agreed amongst ourselves: "This book has enough; there is now no more to be said about it"? (1877; my emphasis)

The answers to these two questions are obvious: "No one" and "Never," or perhaps even the ravenly: "Nevermore." Montaigne's diagnosis back in the times that seem so much simpler than ours is gloomy: "we darken and bury intelligence;" he argues, "we can no longer discover it, but at the mercy of so many fences and barriers." He employs an animal simile to expose the culprit: "Men do not know the natural disease of the mind; it does nothing but ferret and inquire, and is eternally wheeling, juggling, and perplexing itself 
like silkworms, and then suffocates itself in its work." This sentence hinges on a twofold paradox: cognitive processes are imaged in it as 1) physical contortions of insects that Montaigne must have viewed as brainless ${ }^{1}$, and 2) suicidal attempts ("suffocates itself") which are nevertheless productive ("its work"). Montaigne does not dwell on these aspects of the mind's work, but a hopeful reader would be aware of the silver lining of the silkworm metaphor and envisage a strong, though fine and hardly visible, thread and a very precious fabric whose making begins in such apparently nonsensical circumstances.

The very title of Caroline F. Levander's book signals the return to simple questions and the yearning for balanced commonsensical answers that nevertheless benefit from the intellectual ferment of the past decades. The thin volume written in a style comprehensible to a student but not offensively simplistic in the eyes of the academic teacher goes very far to show that the times when discussions of American literature virtually sagged under methodological and theoretical commentary are over. The point of departure is clear and so are the drifts of Levander's argument. Her focus on space in the title and in the corresponding structure of the book reveals the assumption that, at least with reference to American literature, space, though inevitably interconnected, takes precedence over time. The idea itself is not new. Decades ago the late Professor Michael T. Gilmore spoke about the replacing of European time with American space during his unforgettable seminar on early American bestsellers at Brandeis University. Levander's approach to the issue of space claimed by American literature is, however, different. She argues that it is global, though in fact, as many examples in her book show, it is mainly Pan-American. The genuinely global approach is easier promised than delivered, but the intention counts and gives the publication an edge necessary in a manifesto for our time ${ }^{2}$.

The structure of Levander's book is invitingly simple. The titles of the three parts are definitions of the locations where American literature can be sought and found: "physical places, built environments, and human communities" (2013: 183). Each of the three parts is divided into two chapters whose succinct titles offer answers to the major question of where

In contrast to contemporary animal science. See: "Transcriptome Analysis of the Brain of the Silkworm Bombyx Mori Infected with Bombyx Mori Nucleopolyhedrovirus: A New Insight Into the Molecular Mechanism of Enhanced Locomotor Activity Induced by Viral Infection" by G. Wang, J. Zhang, Y. Shen, Q. Zheng, M. Feng, X. Xiang, and X. Wu published in the Journal of Invertebrate Pathology (2015) 128: 37-43. doi: 10.1016/j. jip.2015.04.001. http://www.ncbi.nlm.nih.gov/pubmed/25912089.

2 In fact, the book is part of Wiley Blackwell Manifestos series. 
is American literature. "In the eye of the beholder" and "on the edge" in Part I (Places), "in the cloud" and "in the house" in Part II (Environments), and finally, "at the club" and "under enemy fire" in Part III (Communities).

The introduction "Discovering American Literature" opens with observations concerning the contemporary book market. Levander offers a clear image of former and current ways of looking for books. In the past, bookstores and buying guides contained sections devoted to national literatures. With the rise of online shopping, the criteria of product classification changed dramatically. The issue of nationality became marginal as the dictate of previous shoppers' preferences delivered the final blow to the concept of a national literary canon. The question concerning the whereabouts of American literature may sound desperate, but it is in fact quite hopeful because it presupposes that there is such a thing as American literature, that the sought object does exist. The outlines of American literature may be fuzzy as the traditional regional divisions may prove useless, but the assumption on which Levander's project rests is that there are real places and virtual spaces where American literature can be found (2013: 4).

The question of what counts or does not count as American literature has been asked many times. The tendency has been, inevitably, toward greater inclusion. What criteria should be applied, asks Levander, the author's nationality, his/her residence at the time of writing, the subject matter, the audience, all of the above criteria or only some? Does the adjective "American" mean just US American or perhaps North, Central, and South American? (2013: 2). Levander is diplomatic enough to avoid speaking of American imperialism and colonies (2013: 7-8), but she nevertheless poses the question of classifying spaces which have been or still are "nominally American": Panama, Guam, Liberia and the green zone in Baghdad (2013: 3). She touches on such political issues, but prefers to dwell in the areas of cultural constructions and indeterminacies, posing general questions: What is literature? What is a text? What are they today in the context of massive technological changes? The sheer number of both old and new texts made available on Google books and in countless digital archives is now overwhelming. Levander seems to cast a nostalgic glance at the earliest histories of American literature published in the first decades of the $20^{\text {th }}$ century, which deplored the flimsiness of the textual corpus (2013: 4, 15). Today, by contrast, the literary historian and critic complains about "a veritable embarrassment of riches" (2013: 4).

Although Levander seems to bring back concepts that used to resonate widely in literary and cultural studies of the past, she in fact repurposes them, shifting and/or enlarging their semantic fields. For example, she ap- 
plies the Mexican historian Edmundo O'Gorman's distinction between discovery and invention of America in the $15^{\text {th }}$ century to conceptualize the making and finding of American literature today (2013: 5-6). She is by no means the first historian of American literature to unearth O'Gorman's idea, whose La invención de América (1958) is still in print, read, and quoted in both Spanish and English ${ }^{3}$, but she is one of the first to put it to a new use. O'Gorman's observation is merely mentioned and taken at its face value in Richard Ruland and Malcolm Bradbury's From Puritanism to Postmodernism (1991: 416) and in the first volume of The Cambridge History of American Literature (Bercovitch 1994: 24), to name just two out of many other books. Invention in Levander's understanding is not so much a historically bound and finite phenomenon preceding discovery. It is much rather a constant reinvention that is spatial rather than temporal and only loosely connected with likewise multiple global discoveries. The sources of Levander's inspiration include both authors and critics. For example, on one hand, she picks Ernest Hemingway's concept of iceberg to refer to synecdochal expressions of American literature in individual authors, movements, and genres (2013: 6), while on the other, she takes her cue from Franco Moretti, whose fascination with the opportunities that open up in the wake of the digitalization of archives she seems to share (Levander 2013: 14).

Moretti has become famous (and notorious) as a proponent of "distant reading," an antidote - as he argues - to the longstanding American tradition of "close reading." Moretti's book Distant Reading (2013) exemplifies erudition, which insatiably seeks to encompass still larger fields, and avidly embraces new technologies that promise to overcome the limitations placed by nature on the time and energy of a single lifetime. His technology-aided method allows him to study 7000 books instead of the usual two, three, ten or twenty, and exemplifies the yearning to have global literature studies analogous to global politics and global economy. Levander does not go quite as far, but she clearly shares Moretti's desire. She finds the perspective of a jumbo jet enticing (a bird's-eye-view would not suffice any more), but despite the panoptic view, she just as willingly zooms in on individual cases and then zooms through entire lifetimes and literary careers on one or two pages of her book.

Levander is indeed at her best when she shows the dynamism of origins and reception of American literature, its constant migrations, mutations, and repurposing "in the global setting" (2013: 11). She repeatedly shows that

3 The Invention of America appeared in English in 1961. 
both audiences and materials (no longer "texts" and still less "literature") are "unorthodox and hybrid" (2013: 12), which she by no means regrets. After all, American literature derives its dynamism and vitality from its transnational identity, its mutability, and its adaptability to a variety of emotional needs the world over $(2013: 16,19,24)$. Examples follow and convince the reader that it is really so. Levander's account of the migration of "Sleepy Hollow" from Europe via America to Ghana is truly breathtaking (2013: 9-11). Her expertise in tracing Pan-American cultural links (most notably those relating to Cuba and Mexico) is undeniable (2013: 24-25), at least from the perspective of a European.

In Part I of her book, Levander enacts a drama of perception, relying on the juxtaposition of center and periphery. The sentence "Beauty is in the eye of the beholder" is another way of saying that "There is no accounting for taste." Even though Levander uses the phrase "in the eye of the beholder" to answer (partially) the central question of her book, she is not really concerned about categories as debatable as taste or beauty. She is, however, interested in the cultural and literary choices readers make, quite apart from the canon (which has anyway been dismantled) and popularity (which is fleeting). She steps aside from her position as a stakeholder in (the business of studying and teaching) American literature and looks at it with the eyes of representatives of other cultural traditions. She begins with the famous author Jorge Luis Borges, who in 1967 published his book Introducción a la literature norteamericana (An Introduction to American Literature, 1971). She considers, for example, the reasons for Borges's interest in a relatively little known poem by the major bard of the American Revolution Philip Freneau, which discloses inconsistencies of the nascent American democracy, which from its glorious beginning excluded some people (e.g. the Indians) (2013: 37-38). Little vignettes that follow are examples of the ways in which authors, themes and texts have been appropriated and reappropriated across geopolitical borders often for political reasons and with little attention given to their literary merit or actual message. Thus while making her point, Levander offers a brief introduction to American literature from the perspective of readers outside the US. Part of the introduction are well known facts (e.g. Edgar Allan Poe's popularity in France, 2013: 46-47), but some observations are refreshingly new to Levander's European readers, especially when she refers to Pan-American cultural networks (2013: 44-46, 47-52).

The direction of her gaze changes in the second chapter of Part I. Levander considers in it the aims of authors who focused on or came from the edges of American identity. Katherine Anne Porter and her writing about 
Mexico are prime examples of Americans as beholders of other cultures. Considering the mutability of US borders for over one hundred years from the beginning of the country's existence, not to mention prior complex colonial history, one can see that "edges" or margins were quite near and quite a part of exploratory efforts of American authors, beginning with the New England canon and the luminaries of the American Renaissance (2013: 64). To Levander the border is "both an actual place and a state of mind" (2013: 66). This assumption allows her to expand further the field of literary and cultural exploration. Her discussion of two widely popular texts, Edward Everett Hale's The Man without a Country (1863) and Richard Harding Davis's Soldiers of Fortune (1897), shows the fluidity of fact and fiction serving jointly patriotic purposes far beyond the original story (2013: 70-76). It is quite significant that much of the chapter is devoted to exploring accounts of war, including also the American Civil War, of which none had been deemed worthy of entering the canon of (high-brow) literature. Ruland and Bradbury dutifully name all the great authors who absented themselves from the Civil War and many of the minor ones who did mention the conflict soon after its end. They conclude ruefully that "direct trace of the great crisis on the novel was not strong" (1991: 185).

By contrast, Lavender discusses briefly not just accounts of war, but accounts by female soldiers cross-dressing and crossing boundaries of countries, regions, and allegiances (2013: 76-78). She allows Julian Hawthorne to shine with remarks culled from his "American of the Future" (1884), in which he sees representative Americans in "those who occupy the nation's ever-expanding borderlands-those who exist somewhere between home and abroad" (qtd. in Levander 2013: 84). And yet, the oxymorons with which Levander closes the chapter (American literature is "both theory and practice," "at once liquid and solid, empty space and pure energy mass everywhere and not anywhere for very long" 2013: 85) are just flourishes.

Part II opens with a chapter on the revolution effected by digital technologies, whose rapid development has already radically changed "the operating assumptions of textuality for readers, authors, librarians, and archivists" (2013: 95). The literary superwoman imagined by Richard Powers in his 1993 novel Galatea 2.2 is becoming almost a reality twenty years later. "American literature exists," Levander argues, for both readers and writers "as a dispersed, federated network of data collection repositories, tools, and resource providers that interact dialogically with readers and authors" (2013: 95). To be quite consistent, Levander would have had to dispense entirely with national designations, and refer to "literature" rather than "American literature." Neither authors nor readers seem to care 
much today about national identities in the virtual space of the internet. Such global phenomena prove that information technologies effected a real change while a multitude of scholars were spinning theories about post- and transnational identity. Levander praises the US as the birthplace of digital innovations, including the internet, which she views as part of American creativity, reinforcing in turn the American values of pluralism and democracy (2013: 97-98). She shows "the links between literary and digital environments" (2013: 99) and stops short of claiming for American literature in the cloud and on the ground the kind of hegemony that it is no longer fashionable to demand.

Commenting on the presence of American literature "in the cloud," Levander raises a whole array of fascinating questions about the impact that "virtual environments and remixed cultures" have on the life of literature "on the ground" (2013: 96), but instead of dwelling on the darker aspects of "diffuseness, malleability, and ubiquity" of American literature in the cloud, she prefers to show how Native American networks of communication prefigured the internet, how Edgar Allan Poe's fascination with cryptography welded together the digital code and literary language, and how Walt Whitman, no doubt inebriated on transcendentalism, envisioned a powerful network that brings the distant near (2013: 99-101). The logical conclusion to this hymn would be an assertion that American poets had invented the internet long before the idea materialized.

A more skeptical historian of the internet might note first of all that "diffuseness, malleability, and ubiquity" opens very wide the door to fraud, manipulation, and erasure. While literature on the ground has been affected by such activities over centuries, the scale of threat has increased rapidly in the internet era. What is more, the optimistic view of the internet's democratic promise ignores an important lesson taught by Alexis de Tocqueville in Chapter XV of his Democracy in America, and stressed by Michael T. Gilmore in Chapter II of his 2003 book Surface and Depth, namely, the threat of the "tyranny of the majority," which democracy and its new tool, the internet, make not only possible but also inescapable. Siding with the majority, Levander defies the tyranny of the canon: "the proliferation of digital archives that venerate canonical authors like Dickinson, Whitman, Melville, or Twain" (2013: 106). She fears the "sanitized synecdoche" for American literature, overlooking however two important points: 1) disparate (fan or society) websites do not really aspire to forming a canon, and 2) selection of reading material is inevitable and the only option for readers who can hardly experience American literature in its totality. Thus it is only 
possible to exchange one synecdoche for another, and replace one reading list with another.

Levander notes that information may disappear from the internet websites (2013: 96), but she focuses not so much on loss as on aggregation of digital experiments in literary environments: the virtual ransacking of the American canon (2013: 101-102), the development of new literary tools (2013: 103), and the rise of collaborative editing (2013: 109). The internet-related literary phenomena Levander mentions are indeed interesting and worthy of further investigation. For example, she complains about the ads that interfere with any internet search. Instead of simply ridiculing them, one might argue that while enticing the internet user to buy related products, they also inadvertently create random but powerful juxtapositions, triggering associations and provoking unintended reactions. The use of the new tool of product placement also answers Levander's central question. Where is American literature? It is on display among other saleable products. Levander notes further that "American Authors on the Web has a Japanese webmaster" (2013: 105-106). She does not develop this point, but "global spaces" is hardly the answer to the related question of where the authority on American literature may reside. One needs to pose and attempt to answer a handful of other questions: Who owns American literature? Who decides what counts as American literature? To what purposes can such ownership and authority be used?

The opposite of "the cloud" in Part Two of Levander's book is "the ground," but she chooses to narrow it down to "the house" and ponder on the presence of American literature in writers' houses which are open to the public. Levander clearly disapproves of the pilgrimages to such places and gladly envisions their destruction by fire (2013: 131). She links such museums with the longing for "terra firma," "a conceptual as well as geographic point of origin" (2013: 117), and immediate access to "authorial affect and complexity" (2013: 118). Viewed from this perspective, the haunting of writers' homes emerges as evidence of "the cult of the author," whom Roland Barthes had pronounced dead and buried to the advantage of the reader, whose visitations seem to confirm his/her power over the dead author (2013: 130). The phenomenon of writers' museums, no doubt an answer to popular demand, is too complex for Levander to do justice to in a handful of sarcastic remarks. Contrary to what Levander says, the author's house need not be "a locus of national nostalgia and homage paying" (2013: 128) or a bastion of "conservative nostalgia for simple times" (2013: 131). Authors' homes are as good as the imagination of the people who run them for profit or for the birds. My own experience of visiting the Old 
Manse, the Homestead, or Twain's wedding-cake of a mansion is entirely different. As a scholar crossing cultural boundaries along with the thresholds of such houses, I was neither nostalgic nor fawning. Instead I was seeking crucial information that comes to the (un/sub)conscious mind through channels other than the word. I also remember visiting museums dedicated to writers who never actually lived in those buildings: the Museum Wolfram von Eschenbach (which is a place of imagination rather than musty smells) or the Buddenbrookhaus in Lübeck (which offers both a wealth of documents and an interpretation of the relations between two literary brothers: Thomas and Heinrich Mann).

In the two chapters of Part III, Levander traces the development of virtual communities of readers in the time of peace and war. She addresses two phenomena related to amateur approaches to literature: the rise of book clubs, on one hand, and of military libraries, on the other. High-brow literary scholars may frown upon the shallowness of debate in Oprah Winfrey's Book Club (OBC), as well as on "the unsophisticated and 'unliterary' nature of her book selections" (2013: 137), but the immediate effect that her shows have on sales has made the most ambitious authors (including Jonathan Franzen) come back to the mighty Oprah hat-in-hand and argue lamely that the difference between high and low does not really matter (2013: 142). This is obviously not true. The existence of popular book clubs, with $\mathrm{OBC}$ at the very top of the massive iceberg, proves that there is an ineradicable difference between the tastes and habits of the ivory tower and Main Street. Even if "American authors don't want to find their literature in book clubs," Levander argues, "many readers don't and won't go anywhere else" (2013: 142). American literature is thus on both sides of the divide. Levander views the book club as "a third place of sorts - a space between institutionalized learning and disorganized leisure, between culture and commerce, and between home and work" (2013: 146). She ennobles the book club by pointing to its longstanding tradition (Book of the Month Club emerged in 1926), while at the same time showing how the book club anticipated the fashion of our time: distance learning (2013: 148). She mentions Henry Canby, a notable defector from the ivory tower to Main Street, and David Horowitz, who seeks to provide "a refreshing antidote" to political correctness of literature professors (2013: 151).

Levander's discussion of books selected and published for military communities, beginning with the American Revolution, is truly fascinating to a reader who assumes that the main prerequisite for reading is leisure. Quoting numerous examples, Levander shows that soldiers in both armies of the Civil War and in later conflicts not only had enough time to read, 
but also experienced the pressing need to seek pastime or reassurance in the virtual space of literary texts. During World War II, the American Services Editions (ASE), which was established in response to the popularity of anthologized collections, set the standards for the pocket book format. Widely read (Levander mentions 22 million readers during the war), the series revolutionized "American publishing and created a new generation of readers" (2013: 172). One would hardly expect Henry James to become a favorite author of soldiers during World War II, but Levander quite surprisingly singles him out, quoting the historian Paul Fussell and testimonials by Siegfried Sassoon or Louis Auchincloss (2013: 174), who enlarge on the joys and benefits of reading James's fiction in wartime. Levander does not mention this fact, perhaps taking it for granted, but many of the young soldiers who developed the habit of reading during World War II, went on to study at universities after the war, some of them eventually becoming professors of English ${ }^{4}$. That too was a revolution. Former soldiers brought to universities not only wartime experience, but also the perspective of people who, without a government program (the GI Bill of 1944) would have never dreamed of completing higher education. The two chapters on communities of readers in the United States address issues that are worth pursuing further and questions that apply to other literatures worldwide. Levander has indeed managed to reformulate and thus render the reception studies attractive and worthwhile.

In the Conclusion entitled "Home as Found," Levander picks two examples of American literature that transcended their bookshelf life. In vivid vignettes, she outlines the afterlife of Uncle Tom's Cabin as an architectural endeavor in Berlin-Zehlendorf, on one hand, and promotion of the opposite ideology of Ayn Rand's Atlas Shrugged in the contemporary Canadian enterprise Lululemon, on the other. The closing remarks of Levander's book make an entertaining reading, but they are all the same a case of overinterpretation. Even though she previously criticized synecdochal approaches to American literature, Levander ends with a clearly synecdochal reading. What is more, neither of the texts she mentions is truly literary. As vehicles for ideological messages, both Uncle Tom's Cabin and Atlas Shrugged are culture products, rather than literary works of art. Thus Levander's selection of examples on the closing pages of her book consciously or perhaps inadvertently testifies to the cultural turn in literary studies. Instead of the traditional comparative studies, which would, for

4 I remember meeting representatives of that generation in English Departments in the United States in the 1980s and 90s. 
example, trace the afterlife of Nathaniel Hawthorne's fiction in the works of Octavio Paz or the new lease of life given to Moby Dick in Lothar-Günther Buchheim's celebrated book Das Boot/The Boat ${ }^{5}$ (and the disappointment in the recent sentimental and entirely predictable retelling in the film In the Heart of the Sea, 2015), Levander picks motifs which are cultural and ideological, and points to their extensions in architectural constructs and subliminal advertising far beyond the US. This does not detract, however, from the comparatist skill she brilliantly demonstrates when reading Kafka through Hawthorne and the other way around in an earlier chapter (2013:48).

J. Hillis Miller is conspicuous by his absence in Levander's book, even though the drift of his argument about the recent rise of (high-brow) literature and its inevitable end in the digital era is comparable (2002: 1-12). Both Miller and Levander counteract the post-postmodern crisis of literary theory by sexing up the traditional pursuits of reception and comparative studies. Both pose questions about teaching, promoting, and making sense of literature at universities (2013: 8, 11-12, 28, 187). Like J. Hillis Miller (2002: 8), Levander asks if it still "make[s] sense to parse knowledge along national pathways in a global era" (2013: 28). Moving along these lines, Moretti not only claims that the era of national literature is over, but he also reveals that this observation had already been voiced by Goethe back in 1827, and was corroborated some twenty years later by Marx and Engels (2013: 44-45). The idea of Weltliteratur must have been different in the early $19^{\text {th }}$ century from what it means today, but the invention of comparative studies has not yet solved the dilemma of national vis-à-vis world literature. Contrary to Levander's argument, the concept of nation need not be static, it need not limit creativity, innovation and expression (2013: 9). The dynamism of Levander's own discussion of American literature is, paradoxically, a good proof of that. The distinctiveness of a national American literature was a crucial question to Gilmore. While it is not so important to Levander, one can hardly claim that she offers a thoroughly post-national approach to literature. Where is Levander's American literature then? One could claim that it is on the fence, between the well-worn ruts of American literary history and the world, which is far too wide and far too dynamic to be completely and definitively charted.

5 The book was published in German in 1973, and translated into English in 1975. The film based on the novel was released in 1981. My copy of the book in English appeared in the series of Cassell Military Paperbacks, which boasts several editions since 1999 and several reprints of most editions. 
Levander's book poses the question of where, which is in itself a very American question. A few other basic questions should follow: once again the question of what counts as American literature. Who is in charge of its popular image? Why and how? And when? In other words, Levander's book, though rich in ideas and examples, does not have enough; there is more to be said. And that is good about it.

\section{References}

Berkovitch, S. and S. R. K. Patell (Eds.) (1994). The Cambridge History of American Literature. Cambridge: Cambridge University Press.

Gilmore, M. T. (2003). Surface and Depth: The Quest for Legibility in American Culture. Oxford: Oxford University Press.

Levander, C. F. (2013). Where is American Literature? Chichester: John Wiley \& Sons.

Miller, J. H. (2002). On Literature. London-New York: Routledge.

Montaigne, M. (1877). Essays of Michel de Montaigne. http://www.gutenberg.org/ files/3600/3600-h/3600-h.htm. DOA: 10 Dec. 2015.

Moretti, F. (2013). Distant Reading. London-New York: Verso.

Ruland, R. and M. Bradbury (1991). From Puritanism to Postmodernism. LondonNew York: Penguin Books.

Tocqueville, A. de (1835). Democracy in America, Vol. 1. http://www.gutenberg. org/files/815/815-h/815-h.htm. DOA: 5 Dec. 2015. 